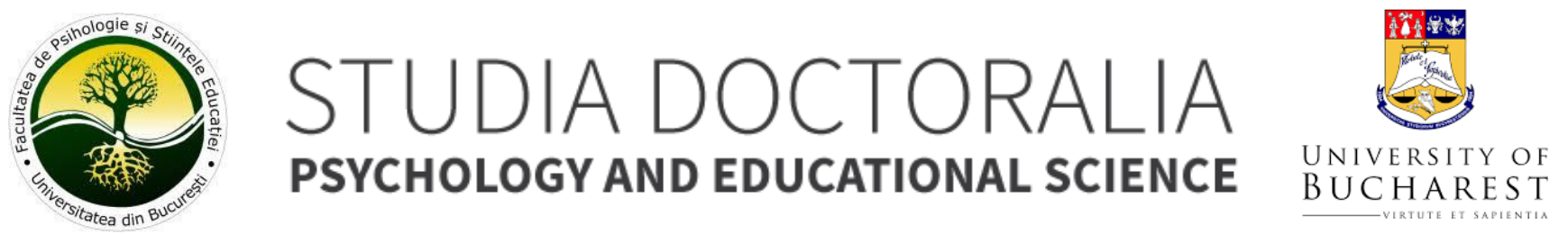

\title{
The role of Dark Triad of personality in the relashionship between attachment type and leadership style
}

\author{
Ecaterina-Bianca Dumitrașcu \\ University of Bucharest
}

\section{ARTICLE INFO}

Article history:

Received 04-February-2020

Accepted 28-April-2020

Available online 01-May-2020

This article should be cited as: Dumitrașcu, E-B. (2020). The role of Dark Triad of personality in the relashionship between attachment type and leadership style. Studia Doctoralia. Psychology and Educational Science, 11(1), 4562.

This is an open access article under the CC BY license (http://creativecommons.org/licenses/by/4.0/).

Corresponding author at: University of Bucharest, Department of Psychology, 90 Panduri Av, Bucharest, RO. Tel.: +40 (0)728 767055 .

E-mail address: bianca.dumitrascu3@gmail.com

\section{ABSTRACT}

Leaders can be found at any hierarchical level of the organization, rapresenting a determinant factor in the global performance and their subordinates' level of job satisfaction. The present study aims to investigate the relationship between the leader's attachment type and his leadership style, but also try to understand how this relationship can be impacted by the presence of accentuated personality traits. In this regard, data was collected using a set of self-report instruments $(N=110)$ from a sample consisting of 72 women $(65.5 \%)$ and 38 men $(34.5 \%)$ which take part in NGOs, between the ages of 19 and 43 years old. Results showed that the anxious attachment type significantly and negatively predicts efficient leadership styles, as opposed to the avoidant type that doesn't seem to share such effects. Moreover, neither of the two insecure attachment types could significantly predict the leader's inefficacy. Regarding to the effect that accentuated personality traits may exhibit, results indicated that Machiavellianism is the only dark trait which has a moderating effect on the relationship between attachment type and leadership style, but only at a lower level of the trait and in a way that reduces the efficacy of the avoidant leader. These results are characterized by a considerable practical importance, mainly in the fields of psychologists and social workers' activity, in organizational selection and training.

Keywords: leadership, attachment type, Dark Triad 


\section{INTRODUCTION}

It is estimated that a leader's failure can cost an organization up to $\$ 2.7$ million, costs derived from wrong decisions, counterproductive work behaviors and high levels of stress and turnover among subordinates (Wiens \& Walker, 2019). In the present era of globalization and restructurations, these costs could lead to the organization's dissolution. Imperative constructs such as the leader's personality, the way he approaches interpersonal relationships and his behaviors are starting to receive more attention.

Reserchers in the organizational field have studied these constructs for a long time. However, in regard to these variables being investigated at an NGO level, there is a lack of general scientific knowledge. As for recent times, in Romania there seems to be a growing interest for the nonprofit field, the volunteering experience being seen as an asset for a job's candidate, the approach of this field thus being important on the account that it can constribute to reducing the gaps in the scientific body of knowledge.

The aim of the present paper is to investigat the way that, in a NGO, the relational past of a leader, his early childhood experiences that shape his attachment type can influence his leadership style and behaviors, but also to try to observe the way that this relation is affected by his personality, more precisely by the presence of the accentuated personality traits.

\section{Attachment type}

Bowlby's Attachment Theory sets to describe and explain the emotional bonds that form between infants and their primary caregivers (Hazan \& Shaver, 1987). This theory implies that, in order to ensure survival, the human race has the sociobiological need to form strong emotional links, referred to as attachments, a system that motivates humans to establish relationships with meaningful persons, seen as attachment figures, with the purpose of protecting oneself from the harsh environment (Romaniello et al., 2015).

These tendencies are regulated by what Bowlby called the Attachment Behavioral System, which consists of motivational functions and the internal dynamics of a homeostatic control system, as its purpose is to maintain a specific stable state by the constant monitoring of both endogenous and exogenous signals and by continuously adjusting the behavior (Fraley \& Shaver, 2000). The stable state desired by this system is represented by physical and psychological proximity of the caregiver, in times of perceived threats or distress (Karantzas, Feeney, \& Wilkinson, 2010).

As Bowlby explained (Bartholomew \& Horowitz, 1991), with time children internalize the experience they have with their caregivers, these emotional bonds thus serving as prototypes for future relationships. If the caregiver is responsive and available, the child learns that he can count on others when needed, but if the caregiver is cold and insensitive, the child may learn that he needs to demand excessive attention or to isolate himself from the group, thus becoming self-sufficient (Fraley \& Shaver, 2000). As it gets older, a person is influenced by various interactions with important figures, this resulting in stable differences in personality and mental representations of emotional bonds that shape its attachment type (Gillath et al., 2005). These are the most accessible mental and behavioral relational schemes of a person. As they build new relationships, people are partially relying on their past experiences, using these models in order to translate the intentions of those around them.

As multiple sources state (Hazan \& Shaver, 1987; Bartholomew \& Horowitz, 1991; Fraley \& Shaver, 2000), in 1978 Ainsworth et al. were the first to organize the individual differences in children's cognition, affection and behavior towards their caregivers, resulting in three attachment types: secure, anxious/ambivalent and avoidant. The key distinction between these types was made based on the different responses an infant can give when separated or reunited with its mother: enjoying contact, seemingly distressed or maintaining distance.

As the time passed, there were multiple models that tried to overlap these patterns with an adult's relational experience. The most commonly known is the one designed by Hazan and Shaver (1987), which indicates that there are three different categories of relational patterns in adults: secure, avoidant and anxious/ambivalent. The first type of adult is characterized trust, friendliness and positive emotions when interacting with others. The avoidant type refers to an adult that is guided in his relationships by fear of bonding, lack of trust and intimacy. As for the anxious/ambivalent one, it is marked by a perpetual and painful attempt to merge with another while fearing rejection. This extrapolation from Ainsworth's typology derives from the fact that the two authors were able to notice similarities between a child's and an adult's needs. In other words, like infants, adults feel safer when their partner is perceived as accessible and responsive. The applicability of this model was indicated by a large number of studies (Mikulincer \& Erev, 1991; Mikulincer \& Nachshon, 1991).

The different types of attahcment were studied in numerous areas of the human nature, especially in reffering to romatic relatioships (Stackert \& Bursik, 2003; Simpson \& Rholes, 2017). But, as this approach tends to lose sight of those too young to have a romantic experience or those who are simply not interested in them (Karantzas et al., 2010), it was later suggested that the Attachment Theory can be applied to any type of relation an adult can establish, on the 
account of meeting three criteria (Davidovitz, Mikulincer, Shaver, Izsak \& Popper, 2007): (1) maintaining proximity, (2) providing a safe haven and (3) providing a secure base.

As they all meet these criteria, the Attachment Theory was later linked to various types of adult relationships, such as friendships (Grabill \& Kerns, 2010), parental roles (Lai \& Carr, 2018), therapeutic alliances (Shapiro et al., 1999) and various others.

\section{The Dark Triad of personality}

The personality traits that encourage a person's tendencies toward antisocial behaviors that defy the cultural and ethical norms of a society were the target of multiple research papers. Initially, they were investigated using clinical samples (Raskin \& Hare, 1978). However, as a large number of individuals tend to daily violate social norms while participating in immoral behaviors, such as cheating, harassment, lying, stealing (Muris, Merckelbach, Otgaar, \& Meijer, 2017), studies started to focus on the subclinical areas too (Giammarco, Atkinson, Baughman, Veselka, \& Vernon, 2013). This refers to the more subtle expression of the disorder that characterizes an individual that tends to participate in fewer norm violating behaviors, but the basic personality characteristics are identic to those who present severe forms of the disorder (Smith \& Lilienfeld, 2013).

The three most popular accentuated personality traits in the domain of research are Machiavellianism, narcissism, and psychopathy. Seeing as the key elements of every act of norm violation tendencies, Paulhus and William (2002) incorporated these traits in the dark triad of the personality. This triad is seen as a constellation of socially undesirable personality traits, both maladaptive and subclinical (Malesza, Ostaszewski, Büchner, \& Kaczmarek, 2017). Thus, although the elements that form the dark triad represent independent constructs, they can be seen as different measures of the same construct, the triad often being referred to as an exploitation social strategy with the sole purpose of avoiding punishment (Jonason, Li, Webser, \& Schmitt, 2009).

The term Machiavellianism originated from Niccolò Machiavelli's piece of work called II Principe (The Prince), in which the Italian politic figure advised kings and lords to maintain power by careful planned acts and, when needed, immoral acts such as the execution of political rivals (Muris et al., 2017). This trait is thus characterized by a cynical view on human nature, lack of moral principles, manipulation, exploitation, flattering and scheming in order to obtain success (Lee et al., 2012; Furnham, Richards, \& Paulhus, 2013).

Narcissism is one of the earliest psychological constructs and was used to describe the attitude of selfcentered patients (Zajenkowski, Witowska, Maciantowicz, \& Malesza, 2016), its research focusing mainly on clinical contexts. The construct of non-pathological, "normal" narcissism was proposed by Raskin and Hall (1979) in their efforts to differentiate between the clinical domain and the sub-clinical one. The term "narcissism" originated from the Greek mythology that tells the story of a young man named Narcissus who was so absorbed by his own beauty that he would treat others with arrogance and contempt. This myth account for the majority of the defining characteristics of the construct, such as vanity, egocentrism, self-admiration that has a negative impact on interpersonal relationships (Campbell, Miller, \& Buffardi, 2010) because of socially aversive behaviors, including excessive self-praise and extreme selfishness. The narcissistic personality can be characterized by a sense grandiosity, superiority (Paulhus \& Williams, 2002) and preoccupations towards fantasies of unlimited power and admiration (Fatfouta, 2018).

The concept of psychopathy derives from psychiatry, where clinicians demarcated systematic observations on a group of patients would frequently get involved in behaviors characterized by reduced empathy, disinhibition and sometimes even superficial charm (Muris et al., 2017). The adaptation of this construct to the subclinical context was the latest of the three elements of the triad (Lilienfeld \& Andrews, 1996). Psychopathy is seen as consisting of high levels of impulsivity and sensation seeking, but also low levels of empathy, remorse, anxiety. Williams, Paulhus and Hare (2007) divided psychopathy in four different facets: antisocial behavior, interpersonal manipulations, disorganized life style and affective insensibility. Of the three traits that are incorporated in the dark triad, psychopathy is seen as the most malicious one (Rauthmann, 2012), as it is often involved in various criminal acts (Hare \& Neumann, 2008).

Despite their distinct origins, the accentuated personality traits that form the dark triad share a number of similarities, such as the tendency toward interpersonal manipulation and exploitation based on self-interests, they are all socially criticized, characterized by affective coldness, duplicity and aggression (Lee et al., 2012; Paulhus \& Williams, 2002). Because they shade similar conceptualizations, correlations and goals, some researchers view them as simple nuances of a general dark personality factor (Jonason \& Webster, 2010).

However, each dark triad element has its unique characteristics that differentiate it from the others. Machiavellianism is the most prone to be shaped environmental factors (Vernon, Villani, Vickers, \& Harris, 2008). It is also characterized by a strategic orientations, while narcissism consists of behaviors oriented towards selfpromotion, and psychopathy is mainly driven by impulsive antisocial behavior (Jones \& Paulhus, 2014). In other words, even in the non-pathological population, there three traits are distinctive enough to allow their individual approach (Paulhus \& Williams, 2002). 


\section{Leadership style}

The construct of leadership has received a multitude of definitions, as its conceptualization is in a constant change depending on the context. After revising the literature, Opoku, Cruickshank and Ahmed (2015) described leadership as the process of influencing a group of people in order to achieve a shared goal, despite not having an executive position in the organization. Thus, leadership can be seen as a human characteristic that can be independent of the hierarchic position that one holds, implying the ability to inspire a shared vision, a general agreement, a change in the beliefs and actions of other in order to reach an organizational goal (Ferding, 2007). These aspects are needed at all the levels of an organization, despite the formal position one occupies (Newton, 2009).

Leadership style can be defined as the effect of the interactions that take place between cognitions regarding to one's self, personality traits, core motivations, thoughts on the operation with situational variables, being a stable behavior that the leader participates in while trying to extend his area of influence (Opoku et al., 2015). There is a large body of leadership styles that were conceptualized by different researchers, but there are some that are viewed as the most notorious ones.

Transformational leadership, described by Bass and Avolio in 1994, is the style that motivates subordinates to exceed the expected level of performance, that encourages them to move their focus from selfish needs to the shared goals of the organization, promoting the satisfaction of need of a superior order (Muchinsky, 2006). The leader's decisions are based on ethical organizational politics, procedures and processes, improving subordinates' motivation, moral and overall performance (Beşikçi, 2019). This style ensures a broader range of interests, personal growth and high levels of self-esteem, stimulating creativity and intelligence, thus being seen as the ideal leadership alternative in organizations (Gryazeva-Dobshinskaya \& Dmitrieva, 2020).

The democratic leadership style allows subordinates to directly contribute to the decisional process of the organization, while still maintaining a relative level of authority of the leaders through his contribution to the final decision. This type of leader promotes a collaborative atmosphere (Boukis, Christos, Daunt, \& Papastathopoulos, 2020), an organizational environment where subordinates can share their feeling, ideas and experiences that are acknowledged by others respectfully (Brookfield, 2010). Transparency and honesty represent key elements of this style that promotes democratic values, moral and instrumental engagement in order to stimulate trust and the legitimate status of the activity (Heide \& Wothy, 2019). Members are therefore invested with equal sets of responsibility and chances to lead the group, thus improving their general leadership abilities (Gastil, 1994).
The autocratic leadership consists of the concentration of all power and authority in the hands of the leader (Harms, Wood, Landay, Lester, \& Vogelgesang Lester, 2017). If using this style, the leader coordinates and sets clear directions regarding the given task (Boukis et al., 2020), directly and completely controlling the team. Members are not invested with freedom as the leader prioritizes the task and puts the human resource on a second plane, strictly maintaining the hierarchic structure of the organization (Peker, İnandı, \& Glıç, 2018). This type of leader has a persistent need of receiving admiration (Burkle, 2019), being characterized by low levels of empathy and anxiety, lack of social and personal conscience that guides his decisional process. Subordinates report lack of trust in the leader, fewer creative solutions to the problems of the organization, lower leadership abilities (Beşikçi, 2019), lack of motivation and loyalty towards the leader.

The transactional leadership style is similar to the traditional model of leading, basing itself on a mutual exchange: subordinates are awarded or punished by the leader when they do meet or not his expectations (Nadu \& Van der Walt, 2005). Thus, this leader focuses on external motivational tactics. The leader focuses on the task and the performance level, neglecting the human resource and its developmental potential (Beşikçi, 2019). Various authors explain that, in this style of leadership, the work relationship doesn't go past its task-reward aspect because of the fact that the leader interferes with his subordinates only when there appear to be obstacles in the completion of the goal (Dartey-Baah, 2020), thus negatively affecting his leading efficacy.

Laissez-faire style comes from the French equivalent of the expression "let them do", consisting of a passive form of leadership in which decision making and responsibilities are avoided by the leader, him being completely uninvolved in the way the organization completes a task, the decisional authority relying in the hands of the subordinates (Gandolfi \& Stone, 2017). Thus, this style is also known as nonleadership (Schyns \& Schilling, 2013), implying the avoidance of the absence of leadership. This types of behaviors generate and maintain a general lack of direction, of information given through the leader's feedback towards his subordinates, of the leader's support when in difficulties.

Strategic leadership implies the ability of anticipation, of flexible maintenance of the organization, of having a clear vision on the organization and while also being able to translate it into actions, being capable of managing both internal and external work environments (Deeboonmee \& Ariratana, 2014). This type of leader establishes a set of strategic priorities and proves efficient when aligning the organization to the external demands (Raisch \& Birkinshaw, 2008). This style influences the cognitive, behavioral, motivational and affective state of the work units (DeChurch, Hiller, Murase, Doty, \& Salas, 2010), being positively 
correlated with both performance and organizational excellence, allowing an efficient competition with other organizations (Abdul Rahman et al., 2019).

Seeing as the styles described above have been correlated with different positive or negative outcomes for the subordinates or the overall organization, they tend to be referred to in literature as efficient leadership styles (which includes the transformational, the democratic and the strategic styles) and inefficient ones (in which are included the autocratic styles, the autocratic and the laissez-faire one).

\section{Attachment type and Dark Triad traits}

The Attachment Theory postulates that the infant's experiences with its caregiver is encoded in personal representations of the self and the others, which in turn affect its cognition, affectivity and behavior (Gillath et al., 2005). These schemas can be seen as the foundation of one's personality, including its accentuated traits (Cohen et al., 2014). Although the dark triad has a shared genetic potential (Vernon et al., 2008), these traits seem to characterize only some individuals of the human species, which supports the supposition that the action of some environmental factors, including the development of an insecure attachment, can play an important role in the traits' evolution. In other words, if the infant perceived its caregivers as responsive to its needs, it will develop a secure attachment that will stop the genetic activation potential of the dark triad, through the encouragement of interpersonal trust and pro-social behavioral tendencies (Jonason, Lyons, \& Bethell, 2014). However, if the primary care received by oneself is perceived as irregular, volatile or even absent, the infant will develop an insecure attachment type, being it avoidant or anxious, that will potentiate the manifestation of the dark triad in the adult life.

Machiavellianism is the most sensitive of the three traits to the action of environmental factors (Vernon et al., 2008), including parental care and attachment type (Láng \& Abell, 2018). Its manifestation is encouraged by the development of an insecure attachment because of the cumulative experiences with neglecting and uninvolved caretakers (Láng \& Lénárd, 2015). When a person expects to be hurt, cheated on or manipulated by the others, Machiavellianism is developed as a maladaptive compensational coping style (Láng \& Birkás, 2014). Although confident on the outside, this type of individual longs for the affection that he lacked in the past. However little emotional interest toward others they may manifest, they are actually dependent on other persons as objects of manipulation.

In the case of narcissism and psychopathy, these traits are less sensitive to the action of environmental factors (Jonason et al., 2014). Still, narcissism seems to share some characteristics with the avoidant attachment pattern, such as the idolization of one-self (Láng \& Birkás, 2014) and it has been linked with poorer relational experiences with the maternal figure. As for psychopathy, although linked with structural and functional brain deficiencies (Anderson \& Kiehl, 2014), it could have been observed that a distant relationship between and infant and the parents helps the development of some impulsive and immediate rewardoriented tendencies, key elements of this accentuated trait (Griskevicius, Tybur, Delton, \& Robertson, 2011).

\section{Attachment type and leadership style}

The idea of the exploration of the links between attachment types and leadership styles originated from Freud's analogy between the leader and a father figure (Eldad \& Benatov, 2018). The Attachment Theory can be incorporated in the leadership domain because of the similar dynamics the infant-caregiver and the subordinate-leader relationships share (Popper \& Mayseless, 2003). Here, the leader plays the role of the stronger and wiser maternal or paternal figure that guides, directs and cares for the subordinate. The latter one shares some aspects with the dependent, vulnerable infant that views the leader as a source of security and protection (Davidovitz et al., 2007). This type of dyad characterized by role inequality allows the subordinate to seek the leader for emotional support and direction (Kafetsios, Athanasiadou, \& Dimou, 2014).

Furthermore, Murphy and Johnson (2011) claimed that the development of a precise leadership style in childhood is plausible, due to the fact that, at that specific age, the behavior, the personality and the abilities of a person are more malleable than in the adult life. Thus, the attachment type that results from the infant's interactions with his parents will more likely determine what type of leader he or she will be in the future (Keller, 2003).

Popper and Mayseless (2007) suggested that one of the important aspects that characterize an efficient leader is a childhood environment rich in emotional stability and supportive parental models. Reviewing the literature, Popper and Amit (2009) found that many great leaders mention in their bibliographic papers having a close relationship with the mother, sometimes even being the favorite sibling, reporting available and attentive caregivers. Descriptions of efficient leaders often resemble those of secure attachment figures (Davidovitz et al., 2007) because of the fact that, in order to ensure high levels of performance, the main method efficient leaders use is one that is similar to the actions of a secure attachment figure, such as providing a sense of security in the followers, through a series of mental processes that facilitate personal growth, a sense of acceptance, autonomy, initiative, creativity (Popper \& Mayseless, 2003).

From an attachment perspective, the key factor in a leader's failure to establish meaningful relationships with his followers is considered him developing insecure relatioships with them. 
The avoidant leader seems to rely only on himself and seeks interpersonal distance, viewing its leading position as an opportunity to demonstrate power, superiority and independence. As this type of leader only focuses on his own person, he will neglect the importance of interpersonal relationships, having difficulties in giving emotional support to those around them (Collins \& Feeney, 2000). This will determine subordinates to perceive the leader as insensible and uncaring (Černe, Batistič, \& Kenda, 2018), reporting lower levels of communication, cohesion and organizational performance (Mayseless, 2010).

As for the anxious leader, he is often guided by his unmet need of affection and the desire to be accepted. His motivation to lead is based on the desire to satisfy his need of attention and security, while still remaining unsure of his ability to coordinate the group (Davidovitz et al., 2007). Because the anxious leader tends to present himself as weak and vulnerable, he will be perceived by followers as inefficient and incapable of leading, too intrusive and ambiguous in evaluations of the performance, this aspects negatively affecting the subordinates' sense of competence and thus promoting dependence to the leader (Černe et al., 2018).

\section{The Dark Triad traits and leadership style}

In recent years, researchers' focus has been shifted from the idealized approach of the "heroic" leaders to a more realistic one, consisting of those leaders that can be destructive for the led group (Furtner, Maran, \& Rauthmann, 2017). The source of this change of perspective is based on the seemingly increasing number of authority abuses, unethical behaviors of leaders and hostile organizational enviroments. Thus, the accentuated personality traits received a considerable amount of interest because they encourage a person to get involved in occupational areas that allows them to obtain power and status (Lyons, 2019).

Machiavellianism is positively associated with desires of power and controlling of others (Mael, Waldman, \& Mulqueen, 2001) in order to exploit them based on selfinterests. This type of leader is perceived by his subordinates as abusive (Kiazad, Restubog, Zagenczyk, Kiewitz, \& Tang, 2010), manipulating, selfish, deceiving which negatively affects their performance and encourages deviant work behaviors (Bordia, Restubog, \& Tang, 2008).

Taking into account the above, we establish the first hypothesis of our study:

\section{METHODOLOGY}

\section{Participants and procedure}

The participants were 110 employees, aged between 19 and $43, \mathrm{M}=22.19, \mathrm{SD}=5.41,72$ women $(65.5 \%)$ and 38 men $(34,5 \%)$, all of which were employees from NGOs. This
H1. Machiavellianism moderates the relationship between attachment type and leadership style.

A narcissistic tendency is viewed as an encouraging factor in one's desire to lead (Kets de Vries \& Miller, 1985), as this kind of influential power represents an optimal selfpromoting social platform (Campbell \& Campbell, 2009). This type of leader is characterized by difficulties in admitting his own mistakes (Hogan \& Kaiser, 2005), fragile ego that responds to perceived threats with aggression and lack of empathy that encourages a decisional system based on selfish motivations (Rosenthal \& Pittinsky, 2006). He starts to be perceived by his subordinates as arrogant, selfcentered and too competitive, encouraging their involvement in maladaptive behaviors such as tax evasion (Olsen \& Stekelberg, 2016) or fraud (Rijsenbilt \& Commandeur, 2013).

Taking into account the above, we establish the second hypothesis of our study:

$\mathrm{H} 2$. Narcissism moderates the relationship between attachment type and leadership style.

The level of psychopathy of those who have an influential power over the organization has been estimated to $4 \%$ (Babiak, Neumann, \& Hare, 2010) compared to its prevalence in the general population that works in one, estimated at only $1 \%$ (Coid, Yang, Ullrich, Roberts, \& Hare, 2009). Boddy (2011) described this type of leader as characterized by aggressive and harsh behaviors towards subordinates, violating the personal and organizational norms. Subordinates perceive the leader as impulsive, selfish, cruel, irrational and even terrifying, which results in a lower level of job satisfaction and higher levels of staff turnover, anxiety and psychological distress (Mathieu, Neumann, Hare, \& Babiak, 2014).

Taking into account the above, we establish the third hypothesis of our study:

H3. Psychopathy moderates the relationship between attachment type and leadership style.

However, research shows that leaders with accentuated personality traits can be benefic in some organizational contexts. For instance, when potential big gains are at stake, these types of leaders can represent an organizational advantage, giving their risk taking situational approach (Lyons, 2013). Thus, in some contexts, as in time of crisis, these leaders are not seen as harmful, especially when success is measured at a general organizational profit level and not at an individual one.

study didn't focus on the executive position or lack thereof held by the participants in the organization.

The research design was cross-sectional and correlational. The data was collected between November 2019 and January 2020. The participants were contacted 
through the social app Facebook in order to redirect them to the online platform Google Forms which made the application of the questionnaire possible. They were informed of the academic and confidential purpose of the obtained data, being aware that they were not to be exposed to any physical or psychological risks.

\section{Instruments}

Attachment type. The attachment type was assessed using a translated version of the Attachment Style Questionnaire - ASQ (Freeney, Noller, \& Hanrahan, 1994), which is a self-report questionnaire consisting of 40 items, each evaluated on a 6-point scale, in which 1 stand for "totally disagree" and 6 for "totally agree". The ASQ was developed in order to include in the attachment study domain those with little romantic experience or that didn't present any interests for them, it being successfully used and validated by many researchers who studied the attachment types in various adult relationships (Troisi, Massaroni, \& Cuzzolaro, 2005; Romaniello et al., 2015) in both clinical and nonclinical samples (Fossati et al., 2003). The questionnaire adapted Hazan and Shaver's attachment model (1987), thus effectively measuring both the avoidant type and the anxious one.
Accentuated personality traits The accentuated personality traits were measured using a translated version of The Short Dark Triad - SD3, developed by Jones and Paulhus (2014) in their efforts to make a concise questionnaire that would not bore or irritate the respondents. The SD3 was successfully adapted to different cultures (Malesza et al., 2017; Özsoy, Rauthmann, Jonason, \& Ardıç, 2017) and consists of 27 items that are self-report and measure Machiavellianism, narcissism and psychopathy using a 5-point Likert format which varies from 1 (strongly disagree) to 5 (strongly agree).

Leadership style was assessed using Opoku's et al. leadership questionnaire (2015), which was developed using elements from the $5 X$ revision of the Multifactor Leadership Questionnaire - MLX (Avolio \& Bass, 2002) and from the Sustainability Leadership Questionnaire - SLQ (McCann \& Holt, 2010). Their questionnaire consists of 18 items that describe specific behavior of six different leadership styles: transformational, democratic, autocratic, transactional, laissez-faire and strategic. Participants' leadership styles are assessed using a 5-point self-report scale, varying from 0 (never) to 4 (frequently, if not always). As the development of the questionnaire was relatively recent, our study is among the firsts to use it in order to measure the leadership style of the participants.

\section{RESULTS}

Table 1. Descriptive statistics

\begin{tabular}{|c|c|c|c|c|c|c|c|c|c|c|c|c|c|c|c|c|}
\hline & M & AS & $A$ & $\mathrm{AE}$ & $\mathrm{AA}$ & MA & NA & PS & LTR & LDE & LAU & LTZ & LLF & LST & LEF & LIN \\
\hline $\mathrm{AE}$ & 55.16 & 11.49 & .83 & 1 & & & & & & & & & & & & \\
\hline AA & 40.87 & 13.24 & .89 & $.61^{* *}$ & 1 & & & & & & & & & & & \\
\hline MA & 26.97 & 6.13 & .75 & $.43^{* *}$ & $.34^{* *}$ & 1 & & & & & & & & & & \\
\hline NA & 28.10 & 5.35 & .60 & $-.24^{*}$ & $-.29 *$ & .18 & 1 & & & & & & & & & \\
\hline PS & 17.84 & 5.55 & 67 & $.35^{* *}$ & $.23^{*}$ & $.52^{* *}$ & $.19^{*}$ & 1 & & & & & & & & \\
\hline LTR & 8.80 & 2.18 & .53 & -10 & -.18 & -.03 & .03 & -16 & 1 & & & & & & & \\
\hline LDE & 7.44 & 2.13 & .57 & -.18 & $-.20^{*}$ & .04 & .12 & -.03 & $.41^{1 * *}$ & 1 & & & & & & \\
\hline LAU & 6.92 & 1.96 & .56 & .07 & -.01 & .08 & .06 & $.20^{*}$ & $.19^{*}$ & .18 & 1 & & & & & \\
\hline LTZ & 8.36 & 1.99 & .55 & $.26^{* *}$ & .11 & $.32^{* *}$ & .04 & .16 & $.37^{* *}$ & $.34^{* *}$ & $.35^{* *}$ & 1 & & & & \\
\hline LLF & 5.98 & 2.14 & .57 & $.21^{*}$ & $.43^{* *}$ & .09 & $-.22^{*}$ & -.11 & -.01 & -.07 & -.07 & -.06 & 1 & & & \\
\hline LST & 9.76 & 1.72 & 64 & .02 & $-.23^{*}$ & .09 & $.21^{*}$ & - 10 & $.59 *$ & $.36^{* *}$ & $.34^{* *}$ & $.49^{*+}$ & .04 & 1 & & \\
\hline LEF & 26.00 & 4.81 & .73 & -.12 & $-.25 *$ & .04 & .14 & -.12 & $.84^{4 *}$ & $.76^{* *}$ & $.29^{* *+}$ & $.49+$ & -.02 & $.79^{*+*}$ & 1 & \\
\hline LIN & 21.26 & 3.74 & .55 & $.29^{* *}$ & $.30^{* *}$ & $.27^{* *}$ & -.07 & .13 & $.29^{* *}$ & $.23^{*}$ & $.67^{* *}$ & $.68^{* *}$ & $.50^{\circ *}$ & $.46^{* *}$ & $.40^{* *}$ & 1 \\
\hline
\end{tabular}

AE - Avoidant attachment, AA - Anxious attachment, MA - Machiavellianism, NA - Narcissism, PS - Psychopathy, LTR - Transformational leadership, LDE - Democratic leadership, LAU - Autocratic leadership, LTZ - Transactional leadership, LLF - Laissez-faire leadership, LST - Strategic leadership, LEF - Efficient leadership, LIN - Inefficient leadership

\section{Hypotheses testing}

For testing the three hypotheses, a series of moderation analyses were conducted, using as predictors the two types of attachment, as moderators, alternatively, the three accentuated personality traits, and as dependent variables the two styles of leadership. The medmod module of Jamovi was used (The jamovi project, 2019).

H1. Machiavellianism moderates the relationship between attachment type and leadership style. 
Table 2. Moderation estimates of Machiavellianism for the relationship between avoidant attachment and efficient leadership

\begin{tabular}{lrrrrrr}
\hline & & & \multicolumn{2}{c}{$95 \%$ Confidence Interval } & & \\
& Estimate & ES & Min. & Max. & Z & P \\
\hline ATEV & -.05 & .04 & -.13 & .02 & -1.38 & .17 \\
MAC & .07 & .07 & -.07 & .22 & 1.03 & .30 \\
ATEV * $*$ MAC & .01 & .01 & .01 & .03 & 2.08 & .04 \\
\hline
\end{tabular}

Table 3. Moderation estimates of the relationship between avoidant attachment and efficient leadership at different values of Machiavellianism

\begin{tabular}{lcccccc}
\hline & & & \multicolumn{2}{c}{$95 \%$ Confidence Interval } & & \\
\cline { 4 - 6 } & Estimate & ES & Min. & Max. & Z & P \\
\hline Average & -.06 & .04 & -.13 & .02 & -1.36 & .17 \\
Low (-1SD) & -.13 & .05 & -.23 & -.03 & -2.61 & .01 \\
High (+1SD) & .02 & .06 & -.09 & .14 & .40 & .69 \\
\hline
\end{tabular}

As seen above, Machiavellianism moderates the relationship between avoidant attachment and efficient leadership, the moderation etimate being .01, Cl95\% (.01, $.03), z=2.08, p<.05$. At average and high levels of Machiavellianism, the relationship between avoidant attachment and efficient leadership is insignificant, and at low level of Machiavellianism, the negative relationship between avoidant attachment and efficient leadership becomes stronger.

Table 4. Moderation estimates of Machiavellianism for the relationship between avoidant attachment and inefficient leadership

\begin{tabular}{lcccccc}
\hline & & & \multicolumn{2}{c}{$95 \%$ Confidence Interval } & & \\
& Estimate & ES & Min. & Max. & Z & P \\
\hline \multirow{2}{*}{ ATEV } & .07 & .03 & .02 & .13 & 2.46 & .01 \\
MAC & .10 & .06 & -.01 & .21 & 1.87 & .06 \\
ATEV * MAC & .01 & .01 & -.01 & .01 & .19 & .85 \\
\hline
\end{tabular}

Tabel 5. Moderation estimates of Machiavellianism for the relationship between anxious attachment and efficient leadership

\begin{tabular}{lrrrrrr}
\hline & & \multicolumn{2}{c}{$95 \%$ Confidence Interval } & & P \\
\cline { 5 - 7 } ATAX & Estimate & ES & Min. & Max. & Z & P \\
MAC & -.10 & .03 & -.20 & -.04 & -3.11 & .00 \\
ATAX * MAC & .10 & .07 & -.04 & .24 & 1.46 & .15 \\
\hline
\end{tabular}


Table 6. Moderation estimates of Machiavellianism for the relationship between anxious attachment and inefficient leadership

\begin{tabular}{lcccccc}
\hline & & & \multicolumn{2}{c}{$95 \%$ Confidence Interval } & & \\
& Estimate & ES & Min. & Max. & Z & P \\
\hline \multirow{2}{*}{ ATAX } & .06 & .03 & .01 & .11 & 2.48 & .01 \\
MAC & .12 & .06 & .01 & .22 & 2.13 & .03 \\
ATAX * MAC & -.00 & .00 & -.01 & .00 & -.93 & .35 \\
\hline
\end{tabular}

The data above shows that Machiavellianism does not moderate the relationship between avoidant attachment and inefficient leadership, niether the relationships between anxious attachment and efficient or inefficient leadership.

H2. Narcissism moderates the relationship between attachment type and leadership style.

Table 7. Moderation estimates of narcisissm for the relationship between avoidant attachment and efficient leadership

\begin{tabular}{lcccccc}
\hline & & & \multicolumn{2}{c}{$95 \%$ Confidence Interval } & & \\
\cline { 6 - 7 } & Estimate & ES & Min. & Max. & z & p \\
\hline ATEV & -.04 & .04 & -.12 & .04 & -1.02 & .31 \\
NAR & .10 & .09 & -.07 & .26 & 1.15 & .26 \\
ATEV * NAR & .00 & .01 & -.01 & .01 & .36 & .72 \\
\hline
\end{tabular}

Table 8. Moderation estimates of narcissism for the relationship between avoidant attachment and inefficient leadership

\begin{tabular}{lccccrc}
\hline & & & \multicolumn{2}{c}{$95 \%$ Confidence Interval } & & \\
& Estimate & ES & Min. & Max. & Z & P \\
\hline ATEV & .10 & .03 & .04 & .16 & 3.40 & .00 \\
NAR & .02 & .06 & -.11 & .14 & .27 & .79 \\
ATEV * NAR & -.01 & .01 & -.01 & .00 & -1.01 & .29 \\
\hline
\end{tabular}

Table 9. Moderation estimates of narcissism for the relationship between anxious attachment and efficent leadership

\begin{tabular}{lcccrrr}
\hline & & & \multicolumn{2}{c}{$95 \%$ Confidence Interval } & & \\
\cline { 5 - 6 } & Estimate & ES & Min. & Max. & Z & P \\
\hline ATAX & -.08 & .03 & -.15 & -.02 & -2.50 & .01 \\
NAR & .06 & .08 & -.10 & .23 & .80 & .44 \\
ATAX * NAR & -.01 & .01 & -.01 & .01 & -.05 & .96 \\
\hline
\end{tabular}


Table 10. Moderation estimates of narcissism for the relationship between anxious attachment and inefficient leadership

\begin{tabular}{lccccrc}
\hline & & & \multicolumn{2}{c}{$95 \%$ Confidence Interval } & & \\
& Estimate & ES & Min. & Max. & $\mathbf{Z}$ & $\mathrm{p}$ \\
\hline \multirow{2}{*}{ ATAX } & .09 & .03 & .04 & .14 & 3.44 & .00 \\
NAR & .02 & .06 & -.11 & .14 & .23 & .81 \\
ATAX * NAR & -.00 & .01 & -.01 & .01 & -.94 & .35 \\
\hline
\end{tabular}

The data above shows that narcissism does not moderate the relationship between avoidant or anxious attachment and efficient or inefficient leadership.
H3.Psychopathy moderates the relationship between attachment type and leadership style

Table 11. Moderation estimate of psychopathy for the relationship between avoidant attachment and efficient leadership

\begin{tabular}{lccccrcr}
\hline & & & \multicolumn{2}{c}{$95 \%$ Confidence Interval } & & \\
\cline { 4 - 5 } & Estimate & ES & Min. & Max. & Z & P \\
\hline \multirow{2}{*}{ ATEV } & -.03 & .04 & -.11 & .05 & -.73 & .47 \\
PSI & -.10 & .08 & -.30 & .06 & -1.19 & .23 \\
ATEV $*$ PSI & .01 & .01 & -.01 & .02 & .69 & .49 \\
\hline
\end{tabular}

Table 12. Moderation estimates of psychopathy for the relationship between avoidant attachment and inefficient leadership

\begin{tabular}{lccccrc}
\hline & & & \multicolumn{2}{c}{$95 \%$ Confidence Interval } & & \\
\cline { 5 - 6 } & Estimate & ES & Min. & Max. & Z & P \\
\hline \multirow{2}{*}{ ATEV } & .09 & .03 & .03 & .15 & 3.08 & .00 \\
PSI & .02 & .06 & -.10 & .14 & .31 & .75 \\
ATEV * PSI & -.01 & .01 & -.01 & .01 & -.01 & .10 \\
\hline
\end{tabular}

Table 13. Moderation estimates of psychopathy for the relationship between anxious attachment and efficient leadership

\begin{tabular}{lcccccc}
\hline & & & \multicolumn{2}{c}{$95 \%$ Confidence Interval } & & \\
\cline { 5 - 6 } & Estimate & ES & Min. & Max. & Z & P \\
\hline \multirow{2}{*}{ ATAX } & -.09 & .03 & -.15 & -.02 & -2.53 & .01 \\
PSI & -.06 & .08 & -.22 & .09 & -.78 & .43 \\
ATAX $*$ PSI & .00 & .01 & -.01 & .02 & .56 & .58 \\
\hline
\end{tabular}


Table 14. Moderation estimates of psycopathy for the relationship between anxious attachment and inefficient leadership

\begin{tabular}{lccccrc}
\hline & & \multicolumn{2}{c}{$95 \%$ Confidence Interval } & & \\
& Estimate & ES & Min. & Max. & Z & P \\
\hline ATAX & .08 & .03 & .03 & .13 & 3.10 & .00 \\
PSI & .04 & .06 & -.08 & .16 & .70 & .50 \\
ATAX * PSI & -.01 & .01 & -.01 & .01 & -.12 & .90 \\
\hline
\end{tabular}

The data above shows that narcissism does not moderate the relationship between avoidant or anxious attachment and efficient or inefficient leadership.

\section{DISCUSSION}

The present study aimed to analyse the relationship between the attachment type and the leadership style, but also the modifications that take place when accentuated personality traits are accounted for.

We focused on the effect that accentuated personality traits (the Dark Triad of personality) have on the relatioship established betweeen the attachment type and leadership styles. Results showed that only Machiavellianism can succesufuly moderate this relatioship, but only at a low level of the trait and only in the case of the link between avoidant attachment and efficient leadership style. In other words it could be noticed that, when focusing only on these two variables, the avoidant attachment doesn't significanlty predict how efficient a leader would be but, when accounted for the level of Machiavellianism, results change, in that the

efficiency of the leader is significantly reduced at a low level of this personality trait. These effects couln't be noticed in when it comes to both moderate and high levels of Machiavellianism. Thus, this hyphothesis was partially accepted.

Previous studies showed contrary results, implying that an avoidant leader's will of demonstrating power, his difficulties in providint emotional support to his subordinates, thus ignoring the importance of the organizational human resourse are amplified by a Machiavellical personality (Wisse \& Sleebos, 2016). This type of leader whould become abusive the moment he perceived himself as powerful, completely neglecting others' wellbeing (Volmer, Koch, \& Göritz, 2016), thus becoming manipulative and selfish while leading, because of his inability to empathize with those around him (Paal \& Berekczkey, 2007). However, there are authors that talk about the importance of Machiavellian tendencies in the act of leading and whose results could explain why an avoidant leader with lower levels of this trait could be less efficient.
Self-image protection, charisma, self-promoting, influencial tactics and the strategic and flexible use of the human and material resources are all Machiavellian behaviors that can accout for the positive outcomes for the leader and his subordinates (Judge, Piccolo, \& Kosalka, 2009). For instance, while reviewing the literature, de Vries (2018) noticed that the Machiavellianism of USA presidents was positively correlated with occupational performance and the number of legislative achievements. Thus, this personality trait is seen as guaranteeing some level of success in terms of obtaining influencial statuses at the job (Spurk, Keller, \& Hirschi, 2015). This approach could explain the negative effect a lower level of Machiavellianism has on the relation between attachment type and efficient leadership styles.

Based on these results, we can consider therefore begin to explin the negative effect that the lower levels of this dark trait have on the relationship between avoidant attachment type and efficient leadership style. When considering the relational detachment and the affective coldness towards others, Machiavellianism and avoidant attachment share some similarities (Láng şi Abell, 2018) that can present negative outcomes on the leadership efficacy, given that some researchers view interpersonal relatioships as the core of leading successfully (Uhl-Bien, 2006). However, some Machiavellical tendencies can make the individual temporarly overcome or hide some of these attitudes in order to achieve and mentain influence (Smith \& Lilienfeld, 2013), the avoidant leader characterized by this accentuated personality traint being better than a non-Machiavellian one at overcoming his desire of interpersonal distancing and thus strategically participating in interactions with others, creating a social network in the organization in order to gain some advantages (Lyons, 2019). This would accont for the fact that a moderate or high level of Machiavellianism does not seem to have a significantly negative impact on the efficacy of the leadership style. Hovewer, at a low level of the trait, where these types of strategic motivations and abilities can't seem be found, it is possible that the avoidant 
attachment of the leader makes him to neglect the relational aspects of his role or his subordinates, thus continuing to distance himself from others. These behaviors could explain why a lower level of Machiavellianism seems to have a significantly negative effect on the avoidant leader's efficiency, contraty to moderate or high levels of the trait, that do not seem to have similar outcomes.

A possible explanation for the fact that Machiavellianism could not seem to have similar effects in the case of anxious attachment can be based on the similarity between the stratategies incorporated in this trait and those incorporated in the avoidant attachment, but not the anxious one. Láng şi Abell (2018) noticed that the emotional detachment and manipulative behaviours that can be found in a Machiavellian individual's strategy seem to share some components with the relational retreat mechanism used by the avoidant one. When accounting for the copind mechanisms activated in interpersonal situations, the anxious attachment differs significantly from those described above, which reduces the chance of its association with the potential effects of Machiavellianism.

Initially, we expected Machiavellianism to positively influence the inefficient leadership style of the insecure attached individual, as the literature accentuates the association of this dark trait and autocratic leadership or the transactional one, based on the neglect of the human resource of the organization (Paal \& Berekczkey, 2007). However, this type of association could not be found in the present study. In this scenario, it is important to associate the present results with those of the researchers that describe the possible positive effects of Machiavellianism in the act of leading. Thus, as Kiazad et al. (2010) stated, some characteristics of the Machiavellian leader, such as charisma, inclination toward planification, self-control, social flexibility, pragmatism and negociation abilities can relatively attenuate its enclinations toward inefficiency while leading.

The fact that Machiavellianism was the only one out of the three trait that seemed to have an effect on the relation between the attachment type and the leadership styles may seen, at a first glance, contraintuitive. Lyons (2019) indicated that individuals with high levels of the dark triad always tend in their organizational life toward maximizing their own gains, contraproductive behaviors such as stealing, absenteeism and intimidation, all of these in the detriment of their peers or subordinates. In regard to narcissism, there are some studies that discourage the labeling of a narcissistic leader as "good" or "bad" (Grijalva, Harms, Newman, Gaddis, \& Fraley, 2015) as a moderated level of this personality trait can have no significant influence on the way a person leads a group, sometimes it being even benefic in leading, through extraversion and boldness.

One possible explanation for our results could be based on Rauthmann's research (2011). In his paper, he stated that narcissism and psychopaty can influence ones perception of self, thus alterating the way these individuals see themselves in comparision to the way they are seen by others. However, the self-descriptions given by individuals at different levels of Machiavellianism seem to corresponde with those given by other people. Thus, as the leadership style questionnaire was a self-report one, we could assume that a Machiavellian leader, however the trait's level, is more prone to describing his behaviours in an accurate manner, which in turn promoted a more realistic self-evaluation when compared to a narcissistic or psychopathic leader, who can show difficulties in admitting his own behaviours.

Our results highlight both the importance of incorporating the Attachment Theory in the organizational field and the necessity to identify leaders with accentuated personality traits, as these two approaches rapresent a unique and efficient way of understanding interpersonal relationship in the organizational setting, this investigative method accounting for both the relational dynamic and individual differences. This paper thus supports Atwater and Yammarionol's (1993) idea that besides being aware of what the leader does, we also need to take into consideration who the leaders is.

\section{Practical implications}

Our results are significant in two major areas. The first area refers to the actions of psychologists and social workers. Any interest manifested in concern to the "dark" aspects of the human nature, including those of leadership, must imply as well the etiological side of them (Jonason et al., 2014). The interventions that target the development of leadership abilities in adults have a reduced positive effect, of only $10 \%$ (Avolio, Reichard, Hannah, Walumbwa, \& Chan, 2009). So, the effect of some influences from the early stages of life in the development of leadership is highlighted, respectively the impact of familial relational context, which represents the basis of a person's attachment type. The results of the present research paper underline the necessity of ensuring a bening environment during childhood, characterised by stability and positive relationships with the caretakers, with the purpose of encouraging the development of pro-social attitudes. As attachment type and personality traits are developed at a very young age and represent the ground for such attitudes (Demircioğlu \& Göncü Köse, 2018), the importance of parental training interventions can not be disputed. This aspect has important implications in the design of leadership programmes that target young leaders, which should focus on the familial component as well. Therefore, the inclusion of the child in familial planning activities, in negociation, in open discussions about problems and feelings could be encouraged, this resulting in a global positive perception of the self and of the ability of becoming an efficient leader (Oliver et al., 2011). It is not mandatory that early adverse experiences result in the child's inefficiency as a leader in 
his adult life, but they increase the chances of such negative effects. So, our research shows the necessity of implementing such interventions in the early moments of an individual's life in order to develop and shape a good leader.

The second area refers to the steps undertaken in organizations, especially when it comes to selection and training. Our results highlighted the importance of attachment types and of accentuated personality traits in understanding the behaviors and the attitudes of the leader, the relational processes in which he partakes and the contribution they have to the experience and the performance of the subordinates.

Regarding the selection process, even though the assessment of one's attachment type has been adviced, there is no organization that utilises this construct as a factor of personnel selection. Harms (2011) explains this phenomena as a result of the strong association between the Theory of Attachment and the bond that forms between children and their caretakers, which makes a majority of the specialists ignore its relevance in the work field. Thus, the organizations can benefit from exploring the early familial experiences during personnel screening, designing an instrument to efficiently measure these issues becoming a neccesity. Also, the neccesity of the instruments dedicated to measuring accentuated personality traits in the selection process is also highlighted. Candidates characterised by Machiavellianism, narcissism and psychopathy are known for their positive self-promotion and superficial charm, which raises their chances of them being employed, in spite of not being trully adequate for that particular job (Lyons, 2019). In other words, in order to avoid errors in the selection process, the assessment of the candidate's dark personality traits is important.

In training, developing the leadership abilities of the members of an organization is a very important aspect because, in both profit and non-profit organizations, executing an efficient leadership is neccesary (Murphy \& Johnson, 2011), no matter the position occupied in the organizational chart. Since attachment types are somewhat malleable (Harms, 2011), the implementation of interventions oriented towards individuals with insecure attachments is possible, in order to prevent the apparition of negative effects of their leading style. So, the development leadership programmes that utilise the principles of the Attachment Theory can focus on promoting a sense of security between the leaders and his subordinates, which will increase the abilities of both partners of the dyad (Hinojosa et al., 2014). The Department of Human Resources can assist during a training programme for developing relational abilities the leaders with insecure attachment types. Accentuated personality traits are also malleable to some degree. Machiavellianism, which was the only variabile in the present study that had a statistically significant effect on the relationship between attachment type and leadership style, is the most predisposed element of the dark triad to the influences of the environment (Vernon et al., 2008). This being said, even though this personality trait is relatively stable throught time, as is narcissism and psycopathy, training programmes could be designed as targeting changes in the cognition, behavior and affectivity of the individual (Fatfouta, 2018). The results of the present research paper also support the posibility that organizations could inform their leaders on the consequences of an inefficient leadership style, even presenting its legal implications (Kiazad et al., 2010).

\section{Limitations}

One of the limitations of this study refers to the self-report instruments which were used in assessing the attachment type, the accentuated personality traits and the leadership style. This aspect could affect the validity of the data provided by our participants, as it is believed that such instruments predispose the study to the apparition of measurement errors, such as social desirability and insufficient self-knowledge. Since the relationships between the variables were observed only at a psychological level and data was not obtained from multiple sources, it can be considered that this aspect affects the current study through a certain degree of subjectivism of the results obtained. However, self-report instruments are useful when the evaluation of subjective states is attempted, such as insecurity of attachment (Ronen \& Zuroff, 2017). Moreover, studies have reportded similarities between the results of single-source measurements and multi-source measurements, both in the case of Machiavellianism (Láng \& Abell, 2018) and the case of work behaviors.

Another limit refers to the instrument of choice in the measurement of leadership style. The one utilised in this study, designed by Opuku and collab. (2015), has reported an internal consistency index of $a=.68$, which can be explained by the specialty literature's disencouraging diversity with regards to the conceptualization of this construct, numerous authors speaking of various leadership styles and instruments for assessing them.

Other than that, the generalization of the results should be made with precaution in the case of Romania but especially when it comes to other cultures, given the relatively low volume of the sample $(N=110)$ and its total composition of participants coming from the population of Romania.

Also, the effect of situational factors on the work-related behaviors was not taken into account, respectively concerning the leadership style, which can raise difficulties in the correct psychological interpretation of the data (Popper et al., 2000). 


\section{REFERENCES}

Abdul Rahman, N. R., Abdul Rahman, S. F., Yaakob, A. M., Masri, R., Ramli, S., \& Ibrahim, Z. (2019). Strategic Leadership, Operational Excellence and Organizational Performance: A Lesson from Japanese Company in Malaysia. International Journal of Recent Technology and Engineering, 8(2S), 291-295.

Aioanei, I. (2006). Leadership in Romania. Journal of Organizational Change Management, 19(6), 705-712.

doi.org/10.1108/09534810610708350

Atwater, L. E., \& Yammarinol, F. J. (1993). Personal Attributes as Predictors of Superiors' and Subordinates' Perceptions of Military Academy Leadership. Human Relations, 46(5), 645-668. doi.org/10.1177/

001872679304600504

Avolio, B. J., \& Bass, B. M. (2002). Manual for the Multifactor Leadership Questionnaire (Form 5X), Mind Garden, Redwood City, CA.

Avolio, B. J., Reichard, R. J., Hannah, S. T., Walumbwa, F. O., \& Chan, A. (2009). A meta-analytic review of leadership impact research: Experimental and quasi-experimental studies. The Leadership Quarterly, 20(5), 764-784.

http://doi.org/10.1016/j.leaqua.2009.06.006

Babiak, P., Neumann, C. S., \& Hare, R. D. (2010). Corporate psychopathy: Talking the walk. Behavioral Sciences \& the Law, 28, 174-193. http://doi.org/10.1002/bsl.925

Bartholomew, K., \& Horowitz, L. M. (1991). Attachment styles among young adults: A test of a four-category model. Journal of Personality and Social Psychology, 61(2), 226244. http://doi.org/10.1037/0022-3514.61.2.226

Ben-Ari, A., \& Lavee, Y. (2005). Dyadic Characteristics of Individual Attributes: Attachment, Neuroticism, and Their Relation to Marital Quality and Closeness. American Journal of Orthopsychiatry, 75(4), 621-631. http://dx.doi.org/ 10.1037/0002-9432.75.4.621

Berson, Y., Dan, O., \& Yammarino, F. J. (2006). Attachment Style and Individual Differences in Leadership Perceptions and Emergence. The Journal of Social Psychology, 146(2), 165-182. https://doi.org/10.3200/SOCP.146.2.165-182

Beşikçi, E. B. (2019). Strategic leadership styles on maritime safety. Ocean Engineering, 185, 1-11. doi.org/10.1016/j.oceaneng.2019.05.046

Boddy, C. R. (2011). Corporate Psychopaths, Bullying and Unfair Supervision in the Workplace. Journal of Business Ethics, 100(3), 367-379. https://doi.org/10.1007/s10551010-0689-5

Bordia, P., Restubog, S. L. D., \& Tang, R. L. (2008). When employees strike back: Investigating mediating mechanisms between psychological contract breach and workplace deviance. Journal of Applied Psychology, 93(5), 1104-1117. https://doi.org/10.1037/0021-9010.93.5.1104

Boukis, A., Koritos, C., Daunt, K. L., \& Papastathopoulos, A. (2020). Effects of customer incivility on frontline employees and the moderating role of supervisor leadership style. Tourism Management, 77, 103997. doi.org/10.1016/j.tourman.2019.103997

Brookfield, S. (2010). Leading democratically. New Directions for Adult and Continuing Education, 128, 5-13. https://doi.org/10.1002/ace.386

Burkle, F. M. (2019). Character Disorders among Autocratic World Leaders and the Impact on Health Security, Human Rights, and Humanitarian Care. Prehospital and Disaster Medicine, 34(1), 2-7. doi.org/10.1017/S1049023X18001280 Campbell, W. K., \& Campbell, S. M. (2009). On the selfregulatory dynamics created by the peculiar benefits and costs of narcissism: A contextual reinforcement model and examination of leadership. Self \& Identity, 8(2-3), 214-232. http://dx.doi.org/10.1080/15298860802505129

Campbell, W. K., Miller, J. D., \& Buffardi, L. E. (2010). The United States and the "Culture of Narcissism": An Examination of Perceptions of National Character. Social Psychological and Personality Science, 1(3), 222-229.

http://dx.doi.org/10.1177/1948550610366878

Černe, M., Batistič, S., \& Kenda, R. (2018). HR systems, attachment styles with leaders, and the creativity-innovation nexus. Human Resource Management Review, 28(3), 271288. https://doi.org/10.1016/j.hrmr.2018.02.004

Cohen, L. J., Tanis, T., Bhattacharjee, R., Nesci, C., Halmi, W., \& Galynker, I. (2014). Are there differential relationships between different types of childhood maltreatment and different types of adult personality pathology? Psychiatry Research, 215(1), 192-201. doi.org/10.1016/ j.psychres.2013.10.036

Coid, J., Yang, M., Ullrich, S., Roberts, A., \& Hare, R. D. (2009). Prevalence and correlates of psychopathic traits in the household population of Great Britain. International Journal of Law and Psychiatry, 32(2), 65-73. http://dx.doi.org/10.1016/j.ijlp.2009.01.002

Collins, N. L., \& Feeney, B. C. (2000). A safe haven: An attachment theory perspective on support seeking and caregiving in intimate relationships. Journal of Personality and Social Psychology, 78(6), 1053-1073. https://doi.org/10.1037/0022-3514.78.6.1053

Dartey-Baah, K. (2020). Leadership Styles and Workplace Wellness Among Ghanaian SME Workers. Advances in Human Factors, Business Management and Leadership, 561-572. https://doi.org/10.1007/978-3-030-20154-8_52

Davidovitz, R., Mikulincer, M., Shaver, P. R., Izsak, R., \& Popper, M. (2007). Leaders as attachment figures: Leaders' attachment orientations predict leadership-related mental representations and followers' performance and mental health. Journal of Personality and Social Psychology, 93(4), 632-650. https://doi.org/10.1037/0022-3514.93.4.632

DeChurch, L. A., Hiller, N. J., Murase, T., Doty, D., \& Salas, E. (2010). Leadership across levels: Levels of leaders and their levels of impact. The Leadership Quarterly, 21(6), 1069-1085. https://doi.org/10.1016/j.leaqua.2010.10.009 
de Vries, R. E. (2018). Three Nightmare Traits in Leaders. Frontiers in Psychology, 9(871). https://doi.org/10.3389/ fpsyg.2018.00871

Deeboonmee, W., \& Ariratana, W. (2014). Relationship between Strategic Leadership and School Effectiveness. Procedia - Social and Behavioral Sciences, 112, 982-985. Demircioğlu, Z. I., \& Göncü Köse, A. (2018). Effects of attachment styles, dark triad, rejection sensitivity, and relationship satisfaction on social media addiction: A mediated model. Current Psychology. https://doi.org/10.1007/s12144-018-9956-x

Eldad, R., \& Benatov, J. (2018). Adult attachment and perceived parental style may shape leadership behaviors. Leadership \& Organization Development Journal, 39(2), 261-275. https://doi.org/10.1108/LODJ-06-2016-0155

Fatfouta, R. (2018). Facets of narcissism and leadership: A tale of Dr. Jekyll and Mr. Hyde? Human Resource Management Review. doi.org/10.1016/j.hrmr.2018.10.002

Fein, E. C., Tziner, A., \& Vasiliu, C. (2010). Age cohort effects, gender, and Romanian leadership preferences. Journal of Management Development, 29(4), 364-376.

https://doi.org/10.1108/02621711011039169

Fossati, A., Feeney, J. A., Donati, D., Donini, M., Novella, L., Bagnato, M., Acquarini, E., Maffei, C. (2003). On the Dimensionality of the Attachment Style Questionnaire in Italian Clinical and Nonclinical Participants. Journal of Social and Personal Relationships, 20(1), 55-79. http://doi.org/10.1177/02654075030201003

Fraley, R. C. (2007). A Connectionist Approach to the Organization and Continuity of Working Models of Attachment. Journal of Personality, 75(6), 1157-1180. http://doi.org/10.1111/j.1467-6494.2007.00471.x

Fraley, R. C., \& Shaver, P. R. (2000). Adult romantic attachment: Theoretical developments, emerging controversies, and unanswered questions. Review of General Psychology, 4(2), 132-154. https://doi.org/10.1037/1089-2680.4.2.132

Furnham, A., Richards, S. C., \& Paulhus, D. L. (2013). The Dark Triad of Personality: A 10 Year Review. Social and Personality Psychology Compass, 7(3), 199-216. https://doi.org/10.1111/spc3.12018

Furtner, M. R., Maran, T., \& Rauthmann, J. F. (2017). Dark Leadership: The Role of Leaders' Dark Triad Personality Traits. Leader Development Deconstructed, 75-99. https://doi.org/10.1007/978-3-319-64740-1_4

Gandolfi, F., \& Stone, S. (2017). The emergence of leadership styles: A clarified categorization. Review of International Comparative Management, 18(1), 18-30.

Gastil, J. (1994). A Meta-Analytic Review of the Productivity and Satisfaction of Democratic and Autocratic Leadership. Small Group Research, 25(3), 384-410. https://doi.org/10.1177/1046496494253003

Giammarco, E. A., Atkinson, B., Baughman, H. M., Veselka, L., \& Vernon, P. A. (2013). The relation between antisocial personality and the perceived ability to deceive. Personality and Individual Differences, 54(2), 246-250. http://dx.doi.org/10.1016/j.paid.2012.09.004

Gillath, O., Shaver, P. R., Mikulincer, M., Nitzberg, R. E., Erez, A., \& ljzendoorn, M. H. (2005). Attachment, caregiving, and volunteering: Placing volunteerism in an attachmenttheoretical framework. Personal Relationships, 12(4), 425446. https://doi.org/10.1111/j.1475-6811.2005.00124.x

Grabill, C. M., \& Kerns, K. A. (2000). Attachment style and intimacy in friendship. Personal Relationships, 7(4), 363378. https://doi.org/10.1111/j.1475-6811.2000.tb00022.x

Grijalva, E., Harms, P. D., Newman, D. A., Gaddis, B. H., \& Fraley, R. C. (2014). Narcissism and Leadership: A MetaAnalytic Review of Linear and Nonlinear Relationships. Personnel Psychology, 68(1), 1-47. doi.org/10.1111/peps. 12072

Griskevicius, V., Tybur, J. M., Delton, A. W., \& Robertson, T. E. (2011). The influence of mortality and socioeconomic status on risk and delayed rewards: A life history theory approach. Journal of Personality and Social Psychology, 100(6), 1015-1026. http://dx.doi.org/10.1037/a0022403

Gryazeva-Dobshinskaya, V. G. \& Dmitrieva, Y. A. (2020). Leadership and Management Styles: Typological Approach to Personal Resources of Change Management. In D. B. Solovev (Ed.), Smart Technologies and Innovations in Design for Control of Technological Processes and Objects: Economy and Production. Smart Innovation, Systems and Technologies (pp. 202-2012).

https://doi.org/10.1007/978-3-030-15577-3

Hare, R. D., \& Neumann, C. S. (2008). Psychopathy as a Clinical and Empirical Construct. Annual Review of Clinical Psychology, 4(1), 217-246. doi.org/10.1146/annurev.clinpsy. 3.022806.091452

Harms, P. D., Spain, S. M., \& Hannah, S. T. (2011). Leader development and the dark side of personality. The Leadership Quarterly, 22(3), 495-509. https://doi.org/10.1016/j.leaqua.2011.04.007

Harms, P. D., Wood, D., Landay, K., Lester, P. B., \& Vogelgesang Lester, G. (2017). Autocratic leaders and authoritarian followers revisited: A review and agenda for the future. The Leadership Quarterly, 29(1), 105-122. https://doi.org/10.1016/j.leaqua.2017.12.007

Hazan, C., \& Shaver, P. (1987). Romantic love conceptualized as an attachment process. Journal of Personality and Social Psychology, 52(3), 511-524. http://dx.doi.org/10.1037/0022-3514.52.3.511

Heide, M., \& Worthy, B. (2019). Secrecy and Leadership: The Case of Theresa May's Brexit Negotiations. Public Integrity, 21(6), 582-594. https://doi.org/10.1080 /10999922.2019.1609273

Hinojosa, A. S., Davis McCauley, K., Randolph-Seng, B., \& Gardner, W. L. (2014). Leader and follower attachment styles: Implications for authentic leader-follower 
relationships. The Leadership Quarterly, 25(3), 595-610. http://dx.doi.org/10.1016/j.leaqua.2013.12.002

Hogan, R., \& Kaiser, R. B. (2005). What we know about leadership. Review of General Psychology, 9(2), 169-180. https://doi.org/10.1037/1089-2680.9.2.169

IBM Corp. Released 2016. IBM SPSS Statistics for Windows, Version 24.0. Armonk, NY: IBM Corp.

Jonason, P. K., Icho, A., \& Ireland, K. (2016). Resources, Harshness, and Unpredictability: The Socioeconomic Conditions Associated With the Dark Triad Traits. Evolutionary Psychology, 14(1), 1-11. http://dx.doi.org/10.1177/1474704915623699

Jonason, P. K., Li, N. P., Webster, G. W., \& Schmitt, D. P. (2009). The Dark Triad: Facilitating short-term mating in men. European Journal of Personality, 23, 5-18.

Jonason, P. K., Lyons, M., \& Bethell, E. (2014). The making of Darth Vader: Parent-child care and the Dark Triad. Personality and Individual Differences, 67, 30-34. http://dx.doi.org/10.1016/j.paid.2013.10.006

Jonason, P. K., \& Webster, G. D. (2010). The dirty dozen: A concise measure of the dark triad. Psychological Assessment, 22(2), 420-432. https://doi.org/10.1037/a0019265

Jones, D. N., \& Paulhus, D. L. (2014). Introducing the Short Dark Triad (SD3): A Brief Measure of Dark Personality Traits. Assessment, 21(1), 28-41. https://doi.org/10.1177/1073191113514105

Judge, T. A., \& Piccolo, R. F. (2004). Transformational and Transactional Leadership: A Meta-Analytic Test of Their Relative Validity. Journal of Applied Psychology, 89(5), 755768. https://doi.org/10.1037/0021-9010.89.5.755

Judge, T. A., Piccolo, R. F., \& Kosalka, T. (2009). The bright and dark sides of leader traits: A review and theoretical extension of the leader trait paradigm. The Leadership Quarterly, 20(6), 855-875. https://doi.org/10.1016/j.leaqua.2009.09.004

Kafetsios, K., Athanasiadou, M., \& Dimou, N. (2014). Leaders' and subordinates' attachment orientations, emotion regulation capabilities and affect at work: A multilevel analysis. The Leadership Quarterly, 25(3), 512527. http://dx.doi.org/10.1016/j.leaqua.2013.11.010

Karantzas, G. C., Feeney, J. A., \& Wilkinson, R. (2010). Is less more? Confirmatory factor analysis of the Attachment Style Questionnaires. Journal of Social and Personal Relationships, 27(6), 749-780. doi.org/10.1177/ 0265407510373756

Keller, H. (2013). Attachment and Culture. Journal of CrossCultural Psychology, 44(2), 175194. doi.org/10.1177/0022022112472253

Keller, T. (2003). Parental images as a guide to leadership sensemaking: an attachment perspective on implicit leadership theories. The Leadership Quarterly, 14(2), 141160. https://doi.org/10.1016/S1048-9843(03)00007-9
Kets de Vries, M. F. R. K., \& Miller, D. (1985). Narcissism and Leadership: An Object Relations Perspective. Human Relations, 38(6), 583-601. https://doi.org/10.1177/ 001872678503800606

Kiazad, K., Restubog, S. L. D., Zagenczyk, T. J., Kiewitz, C., \& Tang, R. L. (2010). In pursuit of power: The role of authoritarian leadership in the relationship between supervisors' Machiavellianism and subordinates' perceptions of abusive supervisory behavior. Journal of Research in Personality, 44(4), 512-519. doi.org/10.1016/ j.jp.2010.06.004

Lai, Y.-H., \& Carr, S. (2018). A Critical Exploration of ChildParent Attachment as a Contextual Construct. Behavioral Sciences, 8(12), 112-126. doi.org/10.3390/bs8120112

Láng, A., \& Abell, L. (2018). Relationship between interparental functioning and adolescents' level of Machiavellianism: A multi-perspective approach. Personality and Individual Differences, 120, 213-221. http://dx.doi.org/10.1016/j.paid.2017.08.043

Láng, A., \& Birkás, B. (2014). Machiavellianism and perceived family functioning in adolescence. Personality and Individual Differences, 63, 69-74. http://dx.doi.org/10.1016/.jpaid.2014.01.065

Láng, A., \& Lénárd, K. (2015). The relation between memories of childhood psychological maltreatment and Machiavellianism. Personality and Individual Differences, 77, 81-85. http://dx.doi.org/10.1016/j.paid.2014.12.054

Lee, K., Ashton, M. C., Wiltshire, J., Bourdage, J. S., Visser, B. A., \& Gallucci, A. (2012). Sex, Power, and Money: Prediction from the Dark Triad and Honesty-Humility. European Journal of Personality, 27(2), 169-184. http://dx.doi.org/10.1002/per.1860

Lilienfeld, S. O., \& Andrews, B. P. (1996). Development and Preliminary Validation of a Self-Report Measure of Psychopathic Personality Traits in Noncriminal Population. Journal of Personality Assessment, 66(3), 488-524. https://doi.org/10.1207/s15327752jpa6603_3

Lyons, M. (2019). The Dark Triad in the Workplace, The dark triad of personality: Narcissism, Machiavellianism, and psychopathy in everyday life (137-160). Cambridge, MA: Academic Press. doi.org/10.1016/B978-0-12-8142912.00006-1

Mael, F. A., Waldman, D. A., \& Mulqueen, C. (2001). From Scientific Work to Organizational Leadership: Predictors of Management Aspiration among Technical Personnel. Journal of Vocational Behavior, 59(1), 132-148. https://doi.org/10.1006/jvbe.2000.1783

Malesza, M., Ostaszewski, P., Büchner, S., \& Kaczmarek, M. C. (2017). The Adaptation of the Short Dark Triad Personality Measure - Psychometric Properties of a German Sample. Current Psychology. doi.org/10.1007/s12144-017-9662-0

Mathieu, C., Neumann, C. S., Hare, R. D., \& Babiak, P. (2014). A dark side of leadership: Corporate psychopathy 
and its influence on employee well-being and job satisfaction. Personality and Individual Differences, 59, 8388. http://dx.doi.org/10.1016/j.paid.2013.11.010

Mayseless, O. (2010). Attachment and the leader-follower relationship. Journal of Social and Personal Relationships, 27(2), 271-280. doi.org/10.1177/0265407509360904

McCann, J.T., \& Holt, R.A. (2010). "Servant and sustainable leadership: analysis in the manufacturing environment", International Journal of Management Practice, 4(2), 134148.

Mikulincer, M., \& Erev, I. (1991). Attachment style and the structure of romantic love. British Journal of Social Psychology, 30(4), 273-291. https://doi.org/10.1111/j.20448309.1991.tb00946.x

Mikulincer, M., \& Nachshon, O. (1991). Attachment styles and patterns of self-disclosure. Journal of Personality and Social Psychology, 61(2), 321-331. https://doi.org/10.1037//0022-3514.61.2.321

Muchinsky, P. M. (2006). Psychology applied to work: an introduction to industrial and organizational psychology (8th ed). Belmont, CA: Thomson/Wadsworth.

Muris, P., Merckelbach, H., Otgaar, H., \& Meijer, E. (2017). The Malevolent Side of Human Nature. Perspectives on Psychological Science, 12(2), 183-204. https://doi.org/10.1177/1745691616666070

Murphy, S. E., \& Johnson, S. K. (2011). The benefits of a long-lens approach to leader development: Understanding the seeds of leadership. The Leadership Quarterly, 22(3), 459-470. https://doi.org/10.1016/j.leaqua.2011.04.004

Newton, S. (2009). Editorial: New directions in leadership. Construction Innovation, 9(2), 129-132. https://doi.org/10.1108/14714170910950786

Oliver, P. H., Gottfried, A. W., Guerin, D. W., Gottfried, A. E., Reichard, R. J., \& Riggio, R. E. (2011). Adolescent family environmental antecedents to transformational leadership potential: A longitudinal mediational analysis. The Leadership Quarterly, 22(3), 535-544. doi.org/10.1016/j.leaqua.2011.04.010

Olsen, K. J., \& Stekelberg, J. (2016). CEO Narcissism and Corporate Tax Sheltering. The Journal of the American Taxation Association, 38(1), 1-22. doi.org/10.2308/atax51251

Opoku, A., Ahmed, V., \& Cruickshank, H. (2015). Leadership style of sustainability professionals in the UK construction industry. Built Environment Project and Asset Management, 5(2), 184-201. http://doi.org/10.1108/bepam12-2013-0075

Özsoy, E., Rauthmann, J. F., Jonason, P. K., \& Ardıç, K. (2017). Reliability and validity of the Turkish versions of Dark Triad Dirty Dozen (DTDD-T), Short Dark Triad (SD3-T), and Single Item Narcissism Scale (SINS-T). Personality and Individual Differences, 117, 11-14. doi.org/10.1016/j.paid.2017.05.019
Paal, T., \& Bereczkei, T. (2007). Adult theory of mind, cooperation, Machiavellianism: The effect of mindreading on social relations. Personality and Individual Differences, 43(3), 541-551. doi.org/10.1016/j.paid.2006.12.021

Paulhus, D. L., \& Williams, K. M. (2002). The Dark Triad of personality: Narcissism, Machiavellianism, and psychopathy. Journal of Research in Personality, 36(6), 556-563. https://doi.org/10.1016/s0092-6566(02)00505-6

Peker, S., İnandı, Y., \& Gılıç, F. (2018). The Relationship Between Leadership Styles (Autocratic and Democratic) of School Administrators and the Mobbing Teachers Suffer. European Journal of Contemporary Education, 7(1), 150164. https://doi.org/10.13187/ejced.2018.1.150

Popper, M., \& Amit, K. (2009). Attachment and leader's development via experiences. The Leadership Quarterly, 20(5), 749-763. doi.org/10.1016/j.leaqua.2009.06.005

Popper, M., \& Mayseless, O. (2003). Back to basics: applying a parenting perspective to transformational leadership. The Leadership Quarterly, 14(1), 41-65. https://doi.org/10.1016/S1048-9843(02)00183-2

Popper, M., \& Mayseless, O. (2007). The building blocks of leader development. Leadership \& Organization Development Journal, 28(7), 664-684. doi.org/10.1108/01437730710823905

Popper, M., Mayseless, O., \& Castelnovo, O. (2000). Transformational leadership and attachment. The Leadership Quarterly, 11(2), 267-289. https://doi.org/10.1016/S1048-9843(00)00038-2

Raisch, S., \& Birkinshaw, J. (2008). Organizational Ambidexterity: Antecedents, Outcomes, and Moderators. Journal of Management, 34(3), 375-409. https://doi.org/10.1177/0149206308316058

Raskin, D. C., \& Hare, R. D. (1978). Psychopathy and Detection of Deception In a Prison Population. Psychophysiology, 15(2), 126-136. doi.org/10.1111/j.14698986.1978.tb01348.x

Raskin, R. N., \& Hall, C. S. (1979). A Narcissistic Personality Inventory. Psychological Reports, 45(2), 590-590. http://dx.doi.org/10.2466/pr0.1979.45.2.590

Rauthmann, J. F. (2012). The Dark Triad and Interpersonal Perception: Similarities and Differences in the Social Consequences of Narcissism, Machiavellianism, and Psychopathy. Social Psychological and Personality Science, 3(4), 487-496. doi.org/10.1177/ 1948550611427608

Rijsenbilt, A., \& Commandeur, H. (2013). Narcissus Enters the Courtroom: CEO Narcissism and Fraud. Journal of Business Ethics, 117(2), 413-429. doi.org/10.1007/s10551012-1528-7

Romaniello, C., Farinelli, M., Matera, N., Bertoletti, E., Pedone, V., \& Northoff, G. (2015). Anxious attachment style and hopelessness as predictors of burden in caregivers of patients with disorders of consciousness: A pilot study. Brain 
Injury, 29(4), 466-472. doi.org/10.3109/ 02699052.2014 .989402

Ronen, S., \& Zuroff, D. C. (2017). How does secure attachment affect job performance and job promotion? The role of social-rank behaviors. Journal of Vocational Behavior, 100, 137-148. doi.org/10.1016/j.jvb.2017.03.006 Rosenthal, S. A., \& Pittinsky, T. L. (2006). Narcissistic leadership. The Leadership Quarterly, 17(6), 617-633. https://doi.org/10.1016/j.leaqua.2006.10.005

Shapiro, D., Hardy, G., Aldridge, J., Davidson, C., Rowe, C., \& Reilly, S. (1999). Therapist Responsiveness to Client Attachment Styles and Issues Observed in Client-Identified Significant Events in Psychodynamic-Interpersonal Psychotherapy. Psychotherapy Research, 9(1), 36-53. https://doi.org/10.1080/10503309912331332581

Simpson, J. A., \& Rholes, W. S. (2017). Adult attachment, stress, and romantic relationships. Current Opinion in Psychology, 13, 19-24. doi.org/10.1016/j.copsyc.

Smith, S. F., \& Lilienfeld, S. O. (2013). Psychopathy in the workplace: The knowns and unknowns. Aggression and Violent Behavior, 18(2), 204-218. http://dx.doi.org/10.1016/j.avb.2012.11.007

Spurk, D., Keller, A. C., \& Hirschi, A. (2016). Do bad guys get ahead or fall behind? Relationships of the dark triad of personality with objective and subjective career success. Social Psychological and Personality Science, 7(2), 113121. https://doi.org/10.1177/1948550615609735

Stackert, R. A., \& Bursik, K. (2003). Why am I unsatisfied? Adult attachment style, gendered irrational relationship beliefs, and young adult romantic relationship satisfaction. Personality and Individual Differences, 34(8), 1419-1429. https://doi.org/10.1016/s0191-8869(02)00124-1

The jamovi project (2019). jamovi. (Version 1.1) [Computer Software]. Retrieved from https://www.jamovi.org.

Troisi, A., Massaroni, P., \& Cuzzolaro, M. (2005). Early separation anxiety and adult attachment style in women with eating disorders. British Journal of Clinical Psychology, 44(1), 89-97. https://doi.org/10.1348/014466504X20053

Uhl-Bien, M. (2006). Relational Leadership Theory: Exploring the social processes of leadership and organizing.
The Leadership Quarterly, 17(6), 654-676. https://doi.org/10.1016/j.leaqua.2006.10.007

van ljzendoorn, M. H., \& Sagi-Schwartz, A. (2008). Crosscultural patterns of attachment: Universal and contextual dimensions. In J. Cassidy \& P. R. Shaver (Eds.), Handbook of attachment: Theory, research, and clinical applications ( $p$. 880-905). The Guilford Press.

Vernon, P. A., Villani, V. C., Vickers, L. C., \& Harris, J. A. (2008). A behavioral genetic investigation of the Dark Triad and the Big 5. Personality and Individual Differences, 44(2), 445-452. http://dx.doi.org/10.1016/j.paid.2007.09.007

Voges, J., Berg, A., \& Niehaus, D. J. H. (2019). Revisiting the African origins of attachment research-50 years on from Ainsworth: A descriptive review. Infant Mental Health Journal, 40(6), 799-816. https://doi.org/10.1002/imhj.21821 Volmer, J., Koch, I. K., \& Göritz, A. S. (2017). "The bright and dark sides of leaders' Dark Triad traits: Effects on subordinates' career success and well-being": Corrigendum. Personality and Individual Differences, 108, 226. https://doi.org/10.1016/j.paid.2016.12.027

Wiens, T. K., \& Walker, L. J. (2019). Examining the relationship between bright and dark personality traits in two management samples. Personality and Individual Differences, $\quad 141, \quad 92-100 . \quad$ doi.org/10.1016/ j.paid.2018.12.025

Williams, K. M., Paulhus, D. L., \& Hare, R. D. (2007). Capturing the Four-Factor Structure of Psychopathy in College Students Via Self-Report. Journal of Personality Assessment, $\quad$ 88(2), 205-219. doi.org/10.1080/00223890701268074

Wisse, B., \& Sleebos, E. (2016). When the dark ones gain power: Perceived position power strengthens the effect of supervisor Machiavellianism on abusive supervision in work teams. Personality and Individual Differences, 99, 122-126. https://doi.org/10.1016/j.paid.2016.05.019

Zajenkowski, M., Witowska, J., Maciantowicz, O., \& Malesza, M. (2016). Vulnerable past, grandiose present: The relationship between vulnerable and grandiose narcissism, time perspective and personality. Personality and Individual Differences, 98, 102-106. http://dx.doi.org/10.1016/j.paid.2016.03.092. 